\title{
A life-course approach to co-residence in the Netherlands, $1850-1940$
}

\author{
JAN KOK* AND KEES MANDEMAKERS $†$
}

ABSTRACT. In this article, we study variations in co-residence with kin in the Netherlands in the late nineteenth and early twentieth centuries. We use the reconstructed life courses of 17,527 individuals derived from the Historical Sample of the Netherlands (HSN) database. The life-course approach allows us to look at coresidence from the perspectives of both the receiving households and the co-resident kin. What made households take in relatives and do we find a preference for one type of relative over another? What was the background of people who decided to coreside in another household? How important were family-related 'altruistic' motives compared with economic ones? The outcomes suggest the predominance of altruistic motives for co-residence, apart from persistent inheritance customs in the eastern part of the country.

\section{INTRODUCTION}

Currently, we are witnessing a renewed interest in past household formation and its consequences for individual lives and for society. Several strands of research have revived interest in historical household composition. The first is the study of the micro-demographic impact of particular household constellations. Recent research convincingly demonstrates the importance of household composition for the life chances of individual members; it mattered for survival, well-being, migration and social mobility whether one was part of a complex, a nuclear or a broken family. ${ }^{1}$ Experiencing particular household configurations may even have

\footnotetext{
* Virtual Knowledge Studio for the Humanities and Social Sciences, Amsterdam, and Katholieke Universiteit Leuven (Belgium).

$\dagger$ International Institute of Social History, Amsterdam, and Erasmus University, Rotterdam.
} 
had an impact on decisions in later stages of the life course. ${ }^{2}$ Also, the ageing of the population in contemporary industrialized societies leads to a renewed interest in how the elderly were cared for in the past, to what extent they lived with kin and so on. ${ }^{3}$ Furthermore, scholars from central and eastern Europe are putting the 'European family system' back on the research agenda by tracing the course of the 'Hajnal' line that supposedly divides western and eastern Europe. ${ }^{4}$ In the Eurasian realm, the debate on the comparability and implications of stem-family forms continues. ${ }^{5}$ Finally, there is a strong interest in the impact of late marriage and neolocal household formation on gender relations and the supposedly unique position of women in north-western European history. ${ }^{6}$ New resources and techniques make it possible to address a number of lingering methodological problems that have beset the field of household history from the beginning. These problems have to do with the limited scope of household surveys, the failure to deal properly with the dynamic nature of households, the difficulty of accounting for the number of kin available for potential co-residence and, finally, the difficulty of unearthing motives for co-residence.

A first problem with most of the literature on the subject of household variation is that detailed information is often available only for specific periods and specific localities. The absolute numbers involved are generally modest and do not allow for tests of statistical significance. The necessarily cautious or 'tepid' interpretations of the data do not inspire debate. ${ }^{7}$ Recently, new resources have become available that may overcome these limitations. We refer here to databases that reconstruct complete residential histories of individuals, including those generally ignored in studies of the 'family life cycle' (such as infertile couples, the permanently single, single mothers, migrants). Databases of this kind have already yielded a whole new literature on patterns of leaving home in the past. $^{8}$

The second problem is that censuses and other 'snapshot-like' surveys do not capture the processes of household expansion and contraction. As Hammel and Laslett recognized in their influential 1974 article, 'We find ourselves for the most part forced to discuss a process as if it were in fact a state'. ${ }^{9}$ The fundamental point has been raised about whether households can be 'followed' at all in a meaningful way. We can say a household 'starts' when a couple marries and occupies a dwelling of their own. But when does a household 'end'? With the death of one or even both spouses? Or does the household continue with the successor to headship, as suggested by Laslett and Hammel $?^{10}$ Unless they are defined as 'property-holding corporations', Kertzer deems it futile to chart households longitudinally: 'The only stable unit for study through time is 
the individual'; therefore, he agrees with Elder and Vinovksis, who pleaded for a life-course approach to studying family dynamics: 'What is needed ... are studies that focus on individuals over time, investigating the ways their lives are affected by changing historical circumstances, and determining the degree and nature of variability among individuals in family-related behavior. '11 Likewise, Richard Wall has argued for the adoption of a longitudinal and individual perspective, but concedes that analysis is hindered 'by the deficiencies of the available methodologies [and] the sheer complexity of so many life courses'. ${ }^{12}$

The third problem is that it has proven very difficult to interpret the incidence of specific household types, because the underlying demographic processes (fertility, mortality, migration) are largely unknown. According to Steve Ruggles and others, the numerical dominance of nuclear families in western European (and North American) household structures should by no means be seen as proof of a nuclear-family 'ideal'. By simulating the potential number of close kin with whom one could coreside in old age, it can be shown that people actually tended to live with available kin, and thus lived up to an extended-family norm. ${ }^{13}$ However, the usefulness of such simulations in providing realistic estimations has been put into question. ${ }^{14}$

Finally, even if we can include the number of potential kin, we are still faced with the question of why, and in what circumstances, relatives would share a dwelling. The study of co-residence generally starts only from the point of view of the head of the household, who (perhaps jointly with his partner and other adults) decides whether to take in an additional household member. All too often, the decision-making is simply assumed to be a cost-benefit analysis in which the economic value (e.g. pooled wages, labour, care-giving) of the co-resident family member is assessed. Ruggles has shown that (the rise of) extended families in late-nineteenthcentury Britain and America cannot be explained from this kind of utility calculation. ${ }^{15}$ Moreover, by definition co-residence entails two parties: the receiving household and the co-resident family member, who will have an agenda of his/her own.

In this article, we rise to the challenge posed by Kertzer and Wall in an effort to study the variation in co-residence with kin from a life-course perspective. We make use of a unique dataset, the Historical Sample of the Netherlands (HSN), which traces and stores data on thousands of individuals from the cradle to the grave in all their subsequent households. ${ }^{16}$ Our purpose is threefold. First, we aim to understand the 'logic' of coresidence by looking at both 'parties' involved. We try to understand the variation in the household situation of young adolescents, which is also closely linked with their migration decisions. To what extent does their 
situation in their parental family explain their choice of living (elsewhere) with kin, with non-kin or still with their parents? We also look closely at the households of married couples: can we understand from their situation (e.g. their migration experience, their age, the number of children) whether they took kin into their households and what kind of kin? Secondly, we try to overcome the problem of having to compare dispersed local data by incorporating the entire Netherlands in our study, over a relatively long period. Finally, we recognize the need to take stock of the 'pool' of available kin: only by controlling as much as possible for kin availability can we reveal the propensities of people by class, period and region to live with parents, siblings and others.

In the next section, we set out to summarize the basic findings on Dutch household history in the nineteenth and early twentieth centuries, then in Section III we describe our Historical Sample of the Netherlands, the quality of the sources used to define relations between household members and our method for charting household histories across the life course. In Section IV, we explore co-residence patterns of adolescents and married couples using a multivariate technique.

\section{HOUSEHOLD SIZE AND STRUCTURE IN THE NETHERLANDS}

The historiography of household structures in the Netherlands is characterized by highly generalized discussions of census results, on the one hand, and a small number of detailed local studies on the other. Also, there is little systematic study of the social backgrounds of specific family forms (role of social position, role of migration) and of their cultural backgrounds (role of regional traditions, role of religion).

During the nineteent century, the average size of Dutch households was about 4.7 to 4.9 persons. It is very difficult to compare the nineteenth century with earlier periods, because of the disparate character of the data and the strong regional differences that we will discuss below. However, it is not likely that households had been much larger in the eighteenth or seventeenth centuries. The available evidence suggests that Dutch households reached their historical maximum size during the period of economic expansion in the first half of the seventeeth century and then contracted in parallel with the economic downturn in the subsequent period. ${ }^{17}$ In the first decades of the nineteenth century, average sizes were again relatively high, declining toward the middle of the century. In the final decades of that century, a slight increase is visible, due to a larger number of children. This increase was mainly caused by the decline in infant mortality. Soon, however, the decrease in marital fertility led to a decline in household size. To some extent, this trend was counteracted by 
a rise in nuptiality and a decline in the number of singles. Also, the rise in life expectancy diminished the incidence of broken families. However, when divorce rates picked up in the second half of twentieth century and birth control was adopted universally, average household size went down rapidly. ${ }^{18}$

In the nineteenth century, about one household out of four had a servant living in. The decline of living-in farmhands was counteracted by an increase in domestic service on middle-class farms. After 1900, however, a permanent decline in numbers of living-in personnel occurred. The censuses put non-nuclear-family members together with boarders in the group 'Others'. In 1879, the census counted on average 0.33 'others' in households. Subsequent censuses show a strong decline in this category: by 1960 the number had halved to $0.16 .^{19}$ Conversely, the number of households consisting of persons living alone increased. ${ }^{20}$

The northern and western parts of the country form a region with a very low prevalence of extended households. In line with contemporary sociological thinking, family sociologists in the 1950s ascribed this to the advance of 'individualization' that - in the wake of economic and cultural modernization-spread from the north-western part of the country inland. ${ }^{21}$ In part, this operated through a process of emulation of 'modern', urban life styles. However, later research has shown that already in the pre-modern period nuclear families had been predominant in the north-west. In the Noorderkwartier region (north-western part of the country), Van der Woude counted co-resident kin in merely 3.6 per cent of all households, far less even than the Dutch average of $1960 .{ }^{22}$ The other extreme is found in the south-eastern and, in particular, in the eastern areas of the country. For instance in the arable farming part of Salland in 174831 per cent of all households had co-residing kin. ${ }^{23}$ In the middle of the twentieth century, this figure could still be as high as 50 per cent in the rural regions of the east. ${ }^{24}$ Lastly, an intermediate zone is found in the south-west (Zeeland), in the south (Brabant) and in the central parts of the country (Utrecht).

To account for the marked regional variation in household size, several explanations have been proposed. First, in the commercialized northwestern part of the country, agriculture was small-scale but profitable; in other words, farmers did not have to rely on family labour but could hire help when it was needed. There was a long tradition of seasonal migration of agricultural workers to the coastal reasons, in particular from Germany. ${ }^{25}$ In the southern and eastern regions, agriculture remained a self-sustaining family enterprise for a much longer period. Secondly, inheritance practices played a part as well. In the late nineteenth and early twentieth centuries, the perceived problems of smallholders 
inspired a number of agricultural surveys as well as questionnaires among rural notaries. ${ }^{26}$ In the eastern areas, the descriptions of the notaries suggest a strong connection between impartibility, care contracts and stem-family households. ${ }^{27}$ The designated heir (often the youngest son) stayed on the farm and only became head when the father decided the time had come. The parents would help the heir on the farm as long as they were able. The heir could not compensate his siblings fully for the loss of their equal share in the inheritance. Instead, they had a lifelong right to stay on the farm, provided they were unmarried and helped as best they could. In effect, the heir and his wife were bound by many (often stipulated) obligations to their elderly parents and living-in siblings, in return for the opportunity to farm the family property. Co-residence was especially common on farms that could (still) be managed with family labour, whereas on either small or large farms (the latter could resort to hired help) it occurred less frequently. ${ }^{28}$ Interestingly, the practice could also be found among labourers in the eastern provinces, although less frequently than among farmers. ${ }^{29}$ After the Second World War, coresidence was increasingly perceived as oppressive by younger couples. They sensed their differences from couples in other parts of the country, in particular when the mass media had made people aware of the attractions of modern, urban living. Indeed, the increase in life expectancy led to a considerable extension of the duration of co-residence with parents. ${ }^{30}$

For the other parts of the country, the connections between inheritance and co-residence are much less clear-cut. In the central parts, care contracts (which might involve the co-residence of two married couples) were mentioned in combination with partibility, whereas in the south-west the geographical location of many farms (with narrow plots with only one access to a road) simply prevented their division. This forced impartibility may have stimulated co-residence as well. ${ }^{31}$ In the southern regions, strict partibility was practised. The ensuing fragmentation of holdings reduced the marriage prospects of farmers' children, leading to a late age at marriage as well as high levels of permanent celibacy. In this area, many unmarried siblings stayed together to farm the parental homestead. ${ }^{32}$ Finally, in the commercialized north-western regions, farms were kept intact, but all children were compensated equally because the parents could quite easily lend them money to rent their own farms, as an advance on their inheritance. The parents themselves would move to a house in the village when the time came to pass over the farm to one of their children. $^{33}$

Our knowledge of urban households is rather sketchy. Our recent research suggests that until about 1900 urban and rural areas did not 
differ greatly in the frequency of extended households. ${ }^{34}$ Obviously, the motives for urban co-residence were different from the motives of farming families. Janssens has shown that among (urban) proto-industrial workers, kin co-residence occurred frequently, as successful families acted as magnets to migrating relatives. ${ }^{35}$ However, she also found that in the city of Tilburg, the middle class was even more prone to take in kin. This might be an indication that indeed the more affluent could and did indulge in the Victorian cult of the family, as Ruggles has claimed ${ }^{36}$ Taking in needy family members could only be done by households that could afford to do so and that had some room left in their house. Reports on this phenomenon show that the lowest social classes rarely took their elderly parents into their households, simply because there was no space. ${ }^{37}$ Occasionally, poor relief organizations boarded out elderly persons with kin. In all, in the last decades of the nineteenth century about 12 per cent of urban households were extended with kin. The urban elderly tended to live independently as long as possible. Increasingly, this was made possible with state pensions. Bulder has demonstrated that the elderly without a pension tended to move into the households of their married children, whereas those who received a pension were more likely to live with an unmarried child. ${ }^{38}$

III. HOUSEHOLDS IN THE HISTORICAL SAMPLE

OF THE NETHERLANDS

\section{The database}

The Historical Sample of the Netherlands (HSN) aims to compile lifecourse data as completely as possible for a representative portion of the population of the nineteenth and twentieth centuries. ${ }^{39}$ The sample drawn for this purpose is based on birth registers from the period 1812 to 1922 $(\mathrm{N}=78,000)$. For this article, we make use of the HSN Data Set Life Courses, Release 2008.01, which is now available in two parts: one covering the provinces of Utrecht, Friesland and Zeeland for the birth period $1850-1882(\mathrm{~N}=5,780)$ and the sample from the entire country for the birth period 1883-1922 $(\mathrm{N}=15,707)$. Most of the data for the construction of life courses are extracted from population registers. Dynamic population registers were introduced in 1850 for the whole of the Netherlands. In the early registers, each household was entered on a double page with the head of the household first. The head was followed by his wife (in cases where the head was a married male), children, other relatives and other members of the household. Date and place of birth, relation to the head of the household, sex, marital status, occupation and 
religion were recorded for each individual. All changes occurring in the household were recorded in the register. These changes were usually made at least within a month of the occurrence of an event. New household members arriving after the registration had started were added to the list of individuals already recorded, and those moving out by death or migration were deleted with reference to place and date of migration or date of death. Thus, families and individuals can, in principle, be followed on a day-by-day basis for a long period. ${ }^{40}$

Although very rich in information, the Dutch population registers are not ideal when it comes to household composition. In the earliest registers, spanning the period $1850-1862$, the relation to the head was not recorded, making it impossible to identify co-resident kin with certainty. Furthermore, from 1862 onwards, servants, boarders and lodgers were recorded in many localities in separate registers. Not only does this make it difficult to distinguish between servants, on the one hand, and boarders and lodgers on the other, but it is also not always clear who was living alone and who was living-in with non-kin. A further problem is that changes in the relationship to the head were often not updated when the head has passed away. In many cases, the new head is not stated explicitly. Conversely, headship may change explicitly but without a properly recorded date. This means that we have had to create some algorithms to deal with implicit headship changes: the widow or abandoned wife comes first; if she is not present, then the eldest married son, and if he is absent then the eldest son-in-law, and so on.

Population registers remained in use until 1910 or 1920, after which a new form of continuous registration was introduced, consisting of single sheets, so-called 'family cards'. Generally this change only took place in municipalities with over 10,000 inhabitants. The registration unit was no longer the household but the nuclear family. ${ }^{41}$ This meant that co-residing kin were often relegated to separate registers for singles, or at least this happened in a number of cities such as Rotterdam. From 1 January 1940 onwards, the 'personal card' replaced family cards and household registers and the individual person became the registration unit in all municipalities. Since then the population register in each municipality consists of a collection of personal cards. Children and spouses were still listed on the cards of the household head, but only their final departure was mentioned, rendering a dynamic analysis of even nuclear households impossible.

\section{Roles in the household}

During his/her life, an individual can take up various roles within households. These roles are defined through the recorded 'relation to the head'. 
TABLE 1

Possible positions of individuals in a household

\begin{tabular}{ll}
\hline \hline Code & \multicolumn{1}{c}{ Position in the household } \\
\hline A & Alone \\
B & Living-in, not related to the head \\
C & Head \\
D & Spouse of the head \\
E & Child of the head \\
F & Parent of the head \\
G & Grandchild of the head \\
H & Otherwise related to the head \\
\hline
\end{tabular}

In our analysis, we distinguish the roles or positions outlined in Table 1. The shifts and durations of positions in the household across the life course of our research persons already provide rich material for studying life-course differentials (see as examples Figures 1 and 2, below). However, this information does not reveal the household composition in itself, let alone experiences in different, subsequent types of household. Therefore, we approach our data with another algorithm, one that inspects and extracts all relations of household members to the head. Household 'episodes' are split according to the duration of a particular household type. Our household typology is derived from the commonly used Hammel and Laslett scheme, simplified and adapted to the information in the Dutch population registers and to the idiosyncrasies of the Dutch kinship system. For instance, the Dutch language makes no distinction between cousin and niece/nephew, which makes it difficult to separate lateral extensions from vertical ones (See category $4 \mathrm{f}$ in Table 2).

An example will serve to demonstrate our procedure. We summarize the life history of one of our research persons (all information originates from the population registers), and then show in Table 3 how the data related to her case are processed in our scheme of household positions and household compositions.

Elisabeth Johanna Verhoef was born on November 16, 1855 in the Lange Nieuwstraat in the city of Utrecht. She was the third child of a joiner, Lodewijk Henricus Wilhelm Verhoef, and his wife Johanna Maria Smit. The religion of the couple was 'Oud Roomsch', a Dutch variant of Anglican. Elisabeth Johanna had two older brothers, whereas younger sisters were born in 1858,1861 and 1864 . In 1865 , the family was hit by the decease of the mother (at age 40 ) and of the youngest girl. The father remarried in 1866, to Maria Loffeld, who was more 
T A B LE 2

Household typology classification used in this study

\begin{tabular}{|c|c|}
\hline \multicolumn{2}{|c|}{ Solitaries and coresidence with non-kin } \\
\hline $1 \mathrm{a}$ & Widow or widower living alone \\
\hline $1 b$ & Unmarried man or woman living alone \\
\hline $1 \mathrm{c}$ & Living as boarder, lodger or servant, or living in an institution \\
\hline
\end{tabular}

No conjugal family unit

2a Unmarried siblings

$2 \mathrm{~b} \quad$ Unmarried relatives

\section{Simple-family households}

3a Married couple without children

3b Married couple with children

$3 \mathrm{c} \quad$ Widow or widower with children

3d Single mother with children

\section{Extended-family households}

4a Extended upward through parent or parent-in-law of head

$4 \mathrm{~b} \quad$ Extended upward through other relative of head

4c Extended downward through grandchild of head

4d Extended laterally through sibling or sibling-in-law of head

$4 \mathrm{e} \quad$ Extended laterally through cousins

4f $\quad$ Extended, lateral or downward

$4 \mathrm{~g} \quad$ Extended with a son-in-law or daughter-in-law

$4 \mathrm{~h} \quad$ Combinations of the above

Multiple-family households

5a Secondary couple extended up

$5 \mathrm{~b} \quad$ Secondary couple extended down, both couples present

$5 \mathrm{c} \quad$ Secondary couple extended down, widow or widower in senior generation

$5 \mathrm{~d} \quad$ Secondary couple extended laterally through sibling

$5 \mathrm{e} \quad$ Combinations of the above

than twenty years younger. They had two children (born in 1868 and 1871) but separated in December 1871. Maria Loffeld left with the baby for the village of Jutphaas, whereas the father remained with three young children: the two oldest boys had already departed at age 16 to Kampen and the West Indies, probably to enlist in the military. Elisabeth Johanna had left earlier, in 1871, to live with an uncle and aunt in Schiedam (province of South Holland). When she returned to Utrecht after six months, she became a servant in the household of Frans Van Exter, a 'Major of Field artillery'. At that time, she was 16 years old. After one year, she went to live as a domestic servant in the vicarage of the 'Oud-Roomsche' priest Cornelius Johannes Mulder. She remained there for ten years until she returned to the home of her father and (half-) brother, for a few months in 1881, then once again she became a servant, this time in the household of Mr Everwijn, 'Inspector of Registration'. Here she remained until her marriage, at 30, on November 3, 1886, to 24-year-old smith Gerardus Jacobus van Zwol. After less than a year their first child, a daughter, was born, followed by a son in 1889 and another in 1893. Her husband became employed by the state railroad company. The family resided for a long time (from 1889 to 1911) at the same address, 
T A B LE 3

An example of changing positions in a household and of household types across the life course: the families of Elisabeth Johanna Verhoef (1855-1931)

\begin{tabular}{|c|c|c|c|c|c|}
\hline Year & Days & Age & Start event & $\begin{array}{l}\text { Position in the } \\
\text { household }\end{array}$ & Household type \\
\hline 1855 & 3,403 & 0 & Birth & E: Child & $\begin{array}{l}\text { 3b: Married couple with } \\
\text { children }\end{array}$ \\
\hline 1865 & 632 & 9 & Death of mother & E: Child & 3c: Widower with children \\
\hline 1866 & 1,657 & 11 & Remarriage of father & E: Child & $\begin{array}{l}\text { 3b: Married couple with } \\
\text { children }\end{array}$ \\
\hline 1871 & 143 & 15 & Migration & H: Related & $\begin{array}{l}\text { 4f: Extended downward } \\
\text { through niece }\end{array}$ \\
\hline 1871 & 259 & 16 & Migration & B: Not related & 1c: Living-in as servant \\
\hline 1872 & 3,109 & 17 & Residential move & B: Not related & 1c: Living-in as servant \\
\hline 1881 & 97 & 25 & Residential move & E: Child & 3c: Widower with children \\
\hline 1881 & 1,965 & 25 & Residential move & B: Not related & 1c: Living-in as servant \\
\hline 1886 & 293 & 30 & Marriage & D: Spouse & $\begin{array}{l}\text { 3a: Married couple without } \\
\text { children }\end{array}$ \\
\hline 1887 & 2,747 & 31 & First child & D: Spouse & $\begin{array}{l}\text { 3b: Married couple with } \\
\text { children }\end{array}$ \\
\hline 1895 & 522 & 39 & $\begin{array}{l}\text { Cousin and half-brother } \\
\text { join the household }\end{array}$ & D: Spouse & $\begin{array}{l}\text { 4h: Extended through } \\
\text { combination }\end{array}$ \\
\hline 1896 & 546 & 40 & Half-brother departs & D: Spouse & 4e: Extended laterally \\
\hline 1898 & 6,829 & 42 & Cousin departs & D: Spouse & $\begin{array}{l}\text { 3b: Married couple with } \\
\text { children }\end{array}$ \\
\hline 1916 & 3,022 & 60 & Husband dies & C: Head & 3c: Widow with children \\
\hline 1925 & 2,162 & 69 & Daughter dies & A: Alone & 1a: Widow living alone \\
\hline
\end{tabular}

Source: HSN Data Set Life Course Release 2008.01, identification number 5249, International Institute of Social History, Amsterdam.

Knipstraat 12, where they were joined for a couple of years by a cousin and the half-brother of Elisabeth Johanna. Her sons left home when they married, respectively in 1913 and 1915, but the daughter stayed with her parents. Elisabeth Johanna's husband died in 1916, and her daughter expired (at age 38) in 1925. Elisabeth Johanna lived alone during the final years of her life, which ended in 1931.

We have calculated the number of person-days that each of the research persons has spent during his or her life in particular positions in the household as well as in particular household structures. This calculation forms the basis for the graphs on household positions of men and women along the life course presented below (see Figures 1 and 2). 


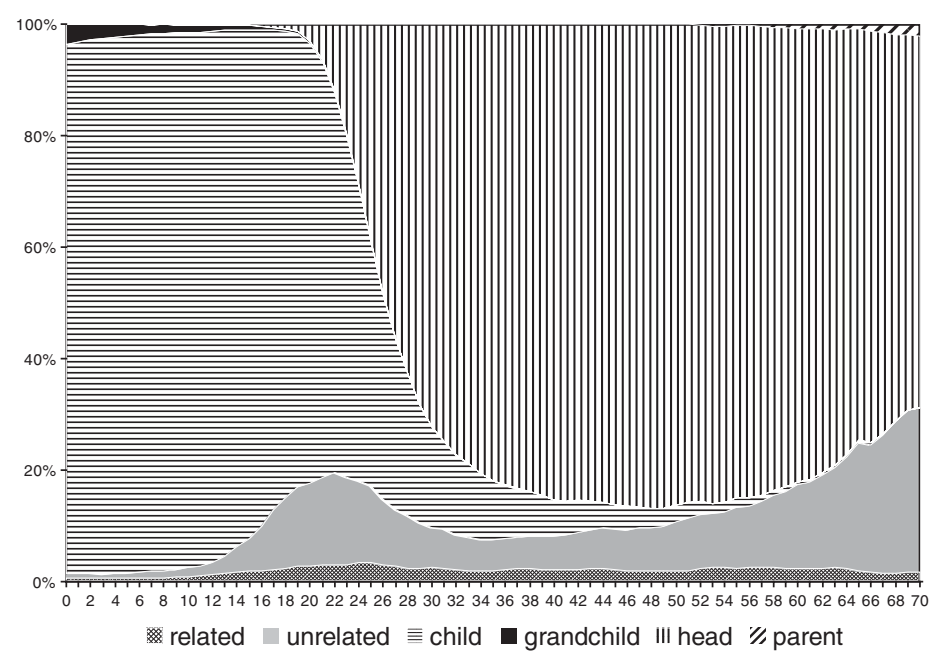

FIgURE 1. Position in the household, by age, of men born in the provinces of Utrecht, Friesland and Zeeland, 1850-1882. (Source: HSN Data Set Life Courses Release 2008.01, International Institute of Social History, Amsterdam.)

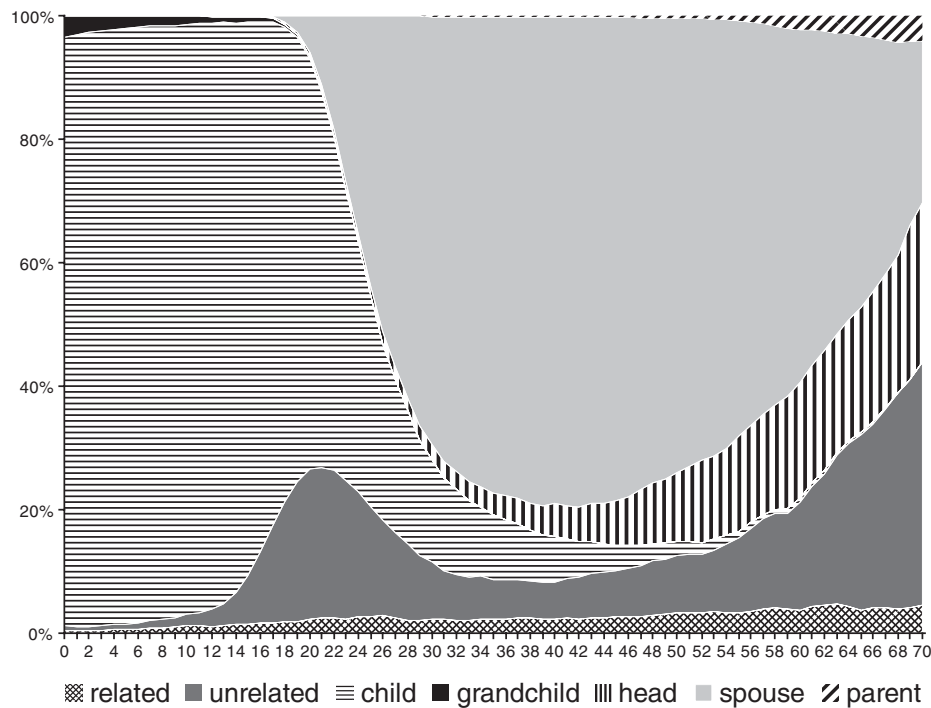

FIGURE 2. Position in the household, by age, of women born in the provinces of Utrecht, Friesland and Zeeland, 1850-1882. (Source: HSN Data Set Life Courses Release 2008.01, International Institute of Social History, Amsterdam.) 
In these figures, we included only the experiences of those in the birth cohorts 1850-1882 in the provinces of Utrecht, Zeeland and Friesland. The other provinces involve younger cohorts, leading to unwanted composition effects. In most of the categories, the figures for men and women are about the same. Obviously, women appear as spouse of the head and then became head themselves as soon as their husbands died. In late adolescence and early adulthood, women lived away from their parents more often than men did, as non-related persons (most of them servants). Men lived somewhat more often than women with relatives in early adolescence, but less often in old age. Women were also more likely in old age to be listed as parent of the head. At age 70, roughly the same proportions of women were 'head' and 'spouse of the head'.

The figures show that three-generation households were scarce: only a small percentage of children lived in households headed by a grandparent and only a few of the elderly lived in a household headed by one of their children. As explained, we cannot make a proper distinction between living alone and residing with non-kin; probably the latter explains the marked concentration of the category 'Unrelated' around age 20, whereas the first increases after age 50 .

Another way of summarizing our data is to look at accumulated experiences across the life course. We selected those individuals from our sample who reached age 70 and who could be observed before 1940 $(\mathrm{N}=801)$, and calculated the proportions of their lives that they spent in a particular household type. Again, this analysis is based on the provinces of Utrecht, Zeeland and Friesland, thus excluding the stem-family region. In Table 4, we compare average proportions by type of birth place, civil status and gender. The 70 -year-olds in this table were all born in the period 1850-1870.42 The table confirms the impression given in Figures 1 and 2 of the relative importance of nuclear families: the men spent 74.5 per cent of their lives in such a household type and the women 72.1 per cent. Whether the men came from a rural or urban background made little difference. However, urban women spent less time in simple-family households than rural women. The difference is accounted for by the longer periods they spent living alone or in non-family households, for example working as a servant. Also, they spent a larger part of their life living with a sibling. As could be expected, the experiences of nevermarried persons differed sharply from those of ever-married ones. The permanently single lived for much longer periods alone or in non-family households and with other unmarried siblings. Remarkably, they were not taken in by married members of the family: the duration of their time living in extended and multiple-family households did not differ from those of ever-married persons. 


\section{TABLE 4}

Average proportions (\%) of life spent in a particular household type, by urban level of place of birth and married status, for research persons born in the provinces of Utrecht, Friesland and Zeeland, 1850-1870

\begin{tabular}{|c|c|c|c|c|c|c|}
\hline & $\begin{array}{l}\text { Solitary/ } \\
\text { non-kin }\end{array}$ & $\begin{array}{c}\text { Unmarried } \\
\text { kin }\end{array}$ & $\begin{array}{c}\text { Simple- } \\
\text { family } \\
\text { household }\end{array}$ & $\begin{array}{l}\text { Extended- } \\
\text { family } \\
\text { household }\end{array}$ & $\begin{array}{l}\text { Multiple- } \\
\text { family } \\
\text { household }\end{array}$ & $N$ \\
\hline \multicolumn{7}{|l|}{ Men } \\
\hline Urban-born & 11.7 & 0.8 & 75.0 & 10.9 & 1.6 & 99 \\
\hline Rural-born & 9.5 & 0.9 & 74.3 & 13.6 & 2.0 & 281 \\
\hline Ever-married & 8.2 & 0.1 & 77.3 & 12.5 & 1.9 & 140 \\
\hline Never-married & 18.8 & 4.3 & 60.6 & 14.2 & 2.1 & 40 \\
\hline All men & 10.0 & 0.9 & 74.5 & 12.8 & 1.9 & 380 \\
\hline \multicolumn{7}{|l|}{ Women } \\
\hline Urban-born & 14.7 & 2.7 & 69.4 & 12.3 & 0.9 & 155 \\
\hline Rural-born & 10.3 & 1.5 & 73.5 & 13.0 & 1.7 & 266 \\
\hline Ever-married & 9.6 & 0.5 & 75.4 & 13.0 & 1.5 & 361 \\
\hline Never-married & 22.9 & 9.0 & 55.6 & 11.6 & 0.9 & 60 \\
\hline All women & 11.8 & 1.9 & 72.1 & 12.8 & 1.4 & 421 \\
\hline
\end{tabular}

Source: HSN Data Set Life Courses Release 2008.01, International Institute of Social History, Amsterdam. The entire dataset consists of 21,487 persons; from this, persons born 1850-1870 were selected.

\section{EXPLAINING VARIATION IN HOUSEHOLDS}

\section{The model}

Why are some households extended and others not? Why are some households extended with parents of the head, others with siblings and yet others with more distant kin? Who is likely to co-reside with kin and what kind of kin will take him/her in? In most household studies, questions that address the issue of propensity to co-reside with particular kin have rarely been answered satisfactorily. It has generally not been possible to take account of the 'pool' of potential kin available for co-residence. Also, it has often proved difficult to compare between households in the same stages of the domestic life cycle, because the numbers involved were often too limited. Furthermore, most studies tend to look at the issue only from the perspective of the receiving household, not from the perspective of the individuals who joined another household. Finally, the dispersed nature of population reconstitutions makes it difficult to compare across periods and regions. In this study, we aim to overcome these limitations by using our large, nationally representative dataset in a multivariate analysis of variation in co-residence. This technique makes it possible to control for 
the many factors that influenced co-residence. Thus, we will look at the nature of the place of birth or current residence (city or not), the region involved (based on the three zones of kin co-residence described above in Section II), ${ }^{43}$ the period and the social class of the household or individuals involved. ${ }^{44}$ In addition, we have included factors that, at least to some extent, measure the pool of available kin.

The technique we have used is called 'multinomial [or polytomous] logistic regression', a variant of binary (or dichotomous) logistic regression. The latter was developed to analyse dependent variables with only two outcomes ('yes' or 'no'). For this situation, a non-linear model is more appropriate than a linear regression. The probability (p) of the dependent variable being a 'yes' or a 'no' is calculated in terms of odds, that is the probability of a 'yes' divided by the probability of a 'no' $(p /(1-p))$. The regression coefficients of the independent variables are the natural logarithms of the odds. By exponentiating the coefficients, we obtain odds ratios. These indicate the increase in the odds of the dependent variable being a 'yes' resulting from an increase of one unit in the independent variable. ${ }^{45}$ In the multinomial variant, the probabilities are calculated in relation to a baseline or reference category. In our first model, for example, the reference group is defined as 'living in a simple family household'. To be sure, we are not modelling causality - that is, we are not connecting the timing of changes in people's situations to the decision to live in another household of a particular type or to take kin into the household. ${ }^{46}$ The model only shows how variation in co-residence is associated with specific variables, such as social background, or with demographic factors, such as the death of the parents.

We have created two models for looking at the household variation at two important junctures in the life course: adolescence and early marriage, in order to look at, respectively, co-residence from the perspectives of persons seeking households to live in and of families deciding to take in kin.

\section{Adolescents}

The first conundrum we need to solve when tackling co-residence from a life-course perspective is the relationship between co-residence and migration. Do decisions to migrate precede the choice of co-residence with kin or non-kin, is it the other way around, or are the two inseparable? We can think of a number of possibilities. First, for many young people in the past, starting training or starting to work implied taking up residence with non-kin. At least, this was the case for farm hands, domestic servants, apprentices and students. When they lived in small communities, this very 
often meant migrating as well. Secondly, when young people left home for other reasons than school or work they were more likely to co-reside with kin. This would involve a migration if the preferred kin were not living nearby. In their impressive study of thousands of British (auto)biographies, Pooley and Turnbull identified family reasons as the second major group of motives for migration, after work. ${ }^{47}$ Indeed, as we have described in the previous section, Elisabeth Johanna Verhoef moved to another city to live with her aunt and uncle at age 15 . This move was very likely caused by a problematic situation at home after the death of her mother and the arrival of her stepmother. Earlier research has shown that the arrival of step-parents often caused tensions in families, leading to the (earlier) departure of children. ${ }^{48}$ In this case, it seems the tensions soon led the stepmother to desert Elisabeth's father. Thirdly, people may have migrated and co-resided with kin to further their prospects in life. In her study of households in the textile city of Tilburg, Janssens has described how relatives used the homes of (successful) kin as stepping stones for their own careers. ${ }^{49}$ Finally, when youths were needed at home, for example to work on the farm, this may have delayed their departure as well as increased the chances that others would be invited to live in as well.

We have divided the co-residential variation of unmarried youths into six groups, in order to handle the various options regarding migration and residence. The reference category (group 1) is the situation in which we find the majority (72.2 per cent) of 20 -year-olds: living in a nuclear family with at least one of the parents. We have removed from our sample of 10,81420 -year-olds those who had already lost both parents $(\mathrm{N}=176)$ because, by definition, orphans cannot be found in the reference category. ${ }^{50}$ Group 2 includes those who were also living with (one of) their parents, but in an extended-family setting. The others had left home: group 3 is made up of those who remained in their place of birth but resided with non-kin, whereas those in group 4 lived with non-kin elsewhere. Group 5 includes youths who were living with relatives in their place of birth, whereas those in group 6 also lived with relatives but had migrated.

In the first model (see Table 5) we related the variations among these groups to factors indicating the social and demographic situation of the family of origin of the adolescents in question. For the sake of simplicity, we reduced residential motives to two major kinds: work-related and family-related motives. We expected that when their work was situated at home, as in the case of farmers, children would be less likely to be found in groups 3-6, but more likely in group 2 , as the parents may have attracted other kin or were obliged to take care of non-inheriting kin or parents, as was the case in the eastern Netherlands. Children from labouring families 
were most likely to be sent out to work as farm hands or domestic servants, ${ }^{51}$ and we expected to find them in groups 3 and 4 . Children from the middle and upper classes often left home and migrated for educational purposes and we expected them to be strongly represented in groups 4 (for example going to boarding schools) and 6. If finding work involved seeking out relatives living elsewhere, as in Janssen's 'stepping stone' hypothesis, it seemed likely that we would find social-background effects in group 6. With respect to family-related reasons, the death of (one of) the parents is likely to have induced departure from home, probably with a preference for going to kin (groups 5 or 6). Other reasons for being sent away from or wanting to leave the parental household could be the age of the parents (too old or too young to be able to handle the household smoothly) and the number of other children.

Table 5 presents the results of this exercise. The model is quite significant and explains about 13 per cent of the individual variation in deviance from the nuclear family. The propensity of unmarried young persons to live with their parent(s) in an extended family (group 2), versus living with (one of) them in a simple family, was lower in urban regions, decreased strongly after $1930{ }^{52}$ was higher in the southwest and, in particular, in the stem-family region of the southeast of the Netherlands; and was higher among the children of farmers, unskilled workers and those whose father had an unknown occupation (relative to skilled workers). With respect to the last category, we have been dealing in many cases with illegitimate children living with their mother in the house of their grandparents. We found that a lower likelihood of 20-year-olds living in an extended family was associated with having more younger siblings. In the model of young couples in Table 6 we can look more closely into the reasons for this.

In terms of the likelihood of co-residence with non-kin (groups 3 and 4) we find strong effects of social background as well, which we take to reflect work-related motives. Children of unskilled workers were very likely to live with non-kin, either in their place of birth or elsewhere. Children from the upper and middle classes were also relatively likely to live with non-kin, but only in a different place. This indicates that, for them, migration to a place where they could receive a training preceded the choice of residence, whereas for the children of unskilled workers the decision to work as a servant or living-in farm hand preceded the migration. Children of farmers were less likely than all the others to live with non-kin. The other significant effects that we find in groups 3 and 4 can be explained as follows. Young people born in cities were, because of the larger pool of opportunities and because of the larger size of population and in area, more likely to live in their natal community than were young people born in the smaller communities of the 


\section{TABLE 5}

Multinomial logistic regression of residence and migration of (single) 20-year-olds born in the Netherlands, 1850-1918 (reference category= group 1: With parents in nuclear family; total $N=10,638)^{a}$

\begin{tabular}{|c|c|c|c|c|c|}
\hline & $\begin{array}{l}2: \text { With } \\
\text { parents in } \\
\text { extended } \\
\text { family }\end{array}$ & $\begin{array}{l}\text { 3: With } \\
\text { non-kin in } \\
\text { place of } \\
\text { birth }\end{array}$ & $\begin{array}{l}\text { 4: With } \\
\text { non-kin } \\
\text { elsewhere }\end{array}$ & $\begin{array}{l}\text { 5: With kin } \\
\text { in place of } \\
\quad \text { birth }\end{array}$ & $\begin{array}{c}6: \text { With } \\
\text { kin } \\
\text { elsewhere }\end{array}$ \\
\hline \multicolumn{6}{|l|}{$\begin{array}{l}\text { Place of birth } \\
\text { (rural = ref.) }\end{array}$} \\
\hline Urban & $0.84 * *$ & $1.35^{* * *}$ & $0.41 * * * *$ & 0.90 & $0.25 * * * *$ \\
\hline \multicolumn{6}{|l|}{ Gender } \\
\hline Woman & 0.94 & $2.91 * * * *$ & $1.72 * * * *$ & 1.15 & 0.76 \\
\hline \multicolumn{6}{|l|}{$\begin{array}{l}\text { Occupational group of } \\
\text { father (skilled } \\
\text { workers }=\text { ref.) }\end{array}$} \\
\hline $\begin{array}{l}\text { Upper and higher } \\
\text { middle class }\end{array}$ & 0.68 & $0.21 * *$ & $2.17 * * *$ & $b$ & 2.80 \\
\hline Lower middle class & 1.10 & $0.66^{* * *}$ & $1.39 * * *$ & 0.98 & $1.96^{*}$ \\
\hline Farmers & $1.40 * * *$ & $0.72 *$ & $0.76^{* *}$ & 1.26 & 1.21 \\
\hline Unskilled workers & $1.28 * * *$ & $1.59 * * * *$ & $1.52 * * * *$ & 1.07 & 1.29 \\
\hline Unknown & $2.11 * * * *$ & 1.39 & $1.50^{* *}$ & 1.39 & 2.30 \\
\hline \multicolumn{6}{|l|}{$\begin{array}{l}\text { Region of birth } \\
\text { (north-west }=\text { ref.) }\end{array}$} \\
\hline South-west & $1.19 * *$ & $0.69 * * * *$ & $1.32 * * * *$ & 0.76 & 1.27 \\
\hline South-east & $2.26 * * * *$ & 0.81 & 0.87 & 1.41 & 0.62 \\
\hline \multicolumn{6}{|l|}{$\begin{array}{l}\text { Period } \\
\qquad(1870-1879=\text { ref. })\end{array}$} \\
\hline $1880-1889$ & 1.16 & $1.38^{*}$ & $1.32 *$ & $0.46^{*}$ & 0.96 \\
\hline $1890-1899$ & 1.15 & $1.41^{*}$ & $1.42 * *$ & 0.69 & 0.82 \\
\hline 1900-1909 & 1.00 & 1.04 & 1.26 & $0.51 * *$ & 1.01 \\
\hline 1910-1919 & 1.12 & $0.61 * * *$ & 1.10 & $0.40 * * *$ & 0.85 \\
\hline 1920-1929 & 0.90 & $0.51 * * * *$ & $0.77 *$ & $0.31 * * * *$ & 0.58 \\
\hline $1930-1938$ & $0.59 * * *$ & $0.33 * * * *$ & $0.57 * * * *$ & $0.22 * * * *$ & 0.52 \\
\hline \multicolumn{6}{|l|}{$\begin{array}{l}\text { Death of parents } \\
\text { (parents alive }=\text { ref.) }\end{array}$} \\
\hline Father dead & 0.90 & $2.00 * * * *$ & 1.13 & $5.65 * * * *$ & $2.30 * * *$ \\
\hline Mother dead & 1.05 & $1.82 * * * *$ & $1.88^{* * * *}$ & $7.33 * * * *$ & $8.84 * * * *$ \\
\hline \multicolumn{6}{|l|}{$\begin{array}{l}\text { Age of the father } \\
(45-54=\text { ref.) }\end{array}$} \\
\hline Younger than 45 & 0.89 & 1.00 & 0.90 & $2.11^{*}$ & 1.01 \\
\hline Between 55 and 64 & 1.02 & 1.09 & 0.97 & 0.78 & 0.61 \\
\hline Older than 64 & 1.07 & $1.50^{*}$ & 1.04 & 1.40 & 0.84 \\
\hline
\end{tabular}


TABLE 5 (cont.)

\begin{tabular}{|c|c|c|c|c|c|}
\hline & $\begin{array}{l}2: \text { With } \\
\text { parents in } \\
\text { extended } \\
\text { family }\end{array}$ & $\begin{array}{c}\text { 3: With } \\
\text { non-kin in } \\
\text { place of } \\
\text { birth }\end{array}$ & $\begin{array}{l}\text { 4: With } \\
\text { non-kin } \\
\text { elsewhere }\end{array}$ & $\begin{array}{l}\text { 5: With kin } \\
\text { in place of } \\
\quad \text { birth }\end{array}$ & $\begin{array}{c}\text { 6: With } \\
\text { kin } \\
\text { elsewhere }\end{array}$ \\
\hline \multicolumn{6}{|l|}{$\begin{array}{l}\text { Age of the mother } \\
(45-54=\text { ref.) }\end{array}$} \\
\hline Younger than 45 & 1.12 & $0.75^{*}$ & 1.06 & $1.87^{*}$ & 1.70 \\
\hline Between 55 and 64 & 0.95 & 0.81 & 0.90 & 1.08 & $2.15^{* *}$ \\
\hline Older than 64 & 0.83 & 0.64 & 0.67 & 1.35 & \\
\hline \multicolumn{6}{|l|}{$\begin{array}{l}\text { Number of surviving } \\
\text { siblings }\end{array}$} \\
\hline Older siblings & 1.01 & 0.97 & 1.02 & $1.09 * *$ & 1.03 \\
\hline Younger siblings & $0.93 * * * *$ & $1.04 *$ & 1.01 & $0.87^{* * *}$ & 0.90 \\
\hline $\mathrm{N}$ & 1,168 & 553 & 1,031 & 133 & 65 \\
\hline Model chi-square & $1,227 * * * *$ & & & & \\
\hline Nagelkerke's r-square & 0.128 & & & & \\
\hline
\end{tabular}

$* 0.1 ; * * 0.05 ; * * * 0.01 ; * * * * 0.001$

${ }^{a}$ See endnote 44 on the occupational-group/social-class categories used here.

${ }^{b}$ Value set to system missing (due to small numbers).

Source: HSN Data Set Life Courses Release 2008.01, International Institute of Social History, Amsterdam. The entire dataset consists of 21.487 persons. From this group, persons have been selected that were born 1850-1918, who were still alive, unmarried and observed at age 20, who were not orphans, and whose parents had known dates of birth.

countryside. The south-west of the country was marked by relatively small-sized communities. Thus, finding work here implied a migration more often than in other regions.

The decline in domestic service in the early twentieth century, when Dutch girls lost their interest in it as alternative work became available, is clearly visible after 1910. Family-related reasons are not absent: children with relatively old fathers tended to leave home to live with non-kin. On the other hand, young persons with relatively young mothers were less likely to live with non-kin. Probably, they were needed at home to assist their mother with household chores. Most important, the death of one of the parents was a major stimulus to leaving home. Interestingly, the death of the father is associated with staying in the natal community, whereas the death of the mother is strongly associated with out-migration. Apparently, working young persons were more eager to remain near their widowed mother than near their widowed father.

Living-in with relatives was also declining in the first decades of the twentieth century. Possibly this indicates that the privatization of family 
life had reached a stage in which siblings and more distant relatives were no longer welcomed as eagerly as some decades earlier. ${ }^{53}$ What is most striking in the last two groups ( 5 and 6 ) is the absence of significant socioeconomic differentials in the propensity to live with kin. We find no indication that young persons from different backgrounds used their distant kin as stepping stones to further their careers. Family-related reasons predominated: the death of one of the parents is a very strong factor, in particular for the young migrating to live with relatives. We see that the death of the mother was associated with an increase in the likelihood of living with kin elsewhere of 884 per cent or more than eight and a half times as much. We also see that having a young father and mother increased the likelihood of living with nearby kin (Group 5). Also, having older siblings increased this likelihood, whereas having younger siblings lowered it. This suggests that children were 'sent' to nearby relatives when the parents were in delicate stages of the family cycle: either at the beginning of family life or at the end. Children who could help with coping with a large family were not sent away, but the youngest children were more likely to move to live with an already-married sibling or other kin.

\section{Married couples}

What induced married couples to take in relatives? As we have seen in our short biography of Elisabeth Johanna Verhoef, she and her husband took in a cousin and a half-brother, some ten years after their marriage. Was this simply inspired by the wish to help them, as Elisabeth herself was helped by her aunt and uncle at age 15? Or were co-residences like this motivated by the needs of the receiving families, such as the need for additional hands on the farm or for assistance with childcare? And, if the (economic) logic of the receiving families prevailed, can we then find patterns in the choices for particular kin, such as parents or siblings? For this final section, we have selected those couples from the HSN for whom the marriage certificate is available. Only on this certificate do we find information about the parents of the partner of the HSN research person. We need this information to control for the death of the parents (and parents-in-law). We also include the number of siblings of the research persons, to control at least to some extent for the pool of available kin.

We compared couples in the same stage of the family life cycle: five years after marriage. Again, we have created a number of groups that diverge from the 'norm' of the nuclear family (reference group 1). Actually, the large majority of the couples lived in the reference group of nuclear households $(90.4 \%$; total $\mathrm{N}=5,316)$. Group 2 includes 
those who did not head their own households, but lived in a multiplefamily households headed by their father or father-in-law. Group 3 is made up of those couples who also lived with one or both parents, but in this case headship rested with the younger generation. Group 4 is couples who co-resided with siblings (or siblings-in-law), either single or married (the latter occurred very rarely). Finally, group 5 consists of more distant kin or combinations of types, such as a half-brother and a cousin.

Does this variation in five different household types tell us something about the motives for co-residence? Families needing additional labour, in particular farming families, were probably more likely to take in siblings or more distant kin than parents. Families that, after five years, had relatively many children, may have been in need of kin (of any kind) to help them out. If altruistic motives were of importance, we may expect people who could afford to take in kin to do so more than others. Unfortunately, the number of elite couples was too small to include them in our model, so we will test this hypothesis with the (lower) middle class. It is also likely that, from an altruistic perspective, siblings were welcomed when one or both of their parents had died.

Table 6 presents a number of interesting results. The second group, representing co-residence with parents, basically shows the backgrounds and social variations in delayed headship transfer. The regional variation stands out: couples living in the stem-family area on the border with Germany had a likelihood of being the secondary unit in a multiplefamily household more than six times higher than for couples in the north-western part of the country. Urban as well as middle-class couples had a reduced likelihood (compared to respectively rural couples and couples of which the male was a skilled worker). We also see that controlling for the number of siblings - even if we only know those of the HSN research persons - is vital. The likelihood of living with parents is related to the number of siblings: the more siblings, the lower the likelihood. Finally, it is interesting that having a higher number of children decreased a couple's chance of being a secondary 'conjugal family unit'. This suggests that a number of couples lived with parents until their own children started to arrive.

The practice of extending the household with parents (as in group 3) was spread evenly over social groups and regions; at least we find no statistically significant differentiation. We do see that it became less popular in the twentieth century. We also see that the more younger siblings one had, the less likely was co-residence with a parent. This means that parents preferred to live as long as possible with an unmarried (often youngest) child and only moved to the household of one of their children 


\section{T A B LE 6}

Multinomial logistic regression of household variation of couples born in the Netherlands, 1850-1922, five years after their marriage (reference category $=$ group 1 : No co-residence; total $N=5,316)^{a}$

\begin{tabular}{|c|c|c|c|c|}
\hline & $\begin{array}{l}\text { 2: Co- } \\
\text { residence } \\
\text { with } \\
\text { parents }\end{array}$ & $\begin{array}{c}\text { 3: Extended } \\
\text { with } \\
\text { parents }\end{array}$ & $\begin{array}{l}\text { 4: Co- } \\
\text { residence } \\
\text { with } \\
\text { siblings }\end{array}$ & $\begin{array}{l}5: \text { Co- } \\
\text { residence } \\
\text { combined } \\
\text { or with } \\
\text { other kin }\end{array}$ \\
\hline \multicolumn{5}{|l|}{ Place of birth (rural = ref.) } \\
\hline Urban & $0.45 * * *$ & 1.08 & $1.43^{* *}$ & 0.75 \\
\hline \multicolumn{5}{|l|}{$\begin{array}{l}\text { Occupational group } \\
\text { (skilled workers = ref.) }\end{array}$} \\
\hline Lower middle class & $0.30^{* *}$ & 0.79 & 1.01 & 0.82 \\
\hline Farmers & $1.89^{*}$ & 1.55 & $1.73^{* *}$ & $2.28 * * *$ \\
\hline Unskilled workers & 1.10 & 0.89 & $0.67 * *$ & 0.79 \\
\hline \multicolumn{5}{|l|}{$\begin{array}{l}\text { Region of residence } \\
\text { (north-west }=\text { ref.) }\end{array}$} \\
\hline South-west & $2.38 * * *$ & 1.38 & 1.14 & $1.67 * *$ \\
\hline South-east & $7.05 * * * *$ & 1.42 & $1.55^{*}$ & $3.38^{* * * *}$ \\
\hline \multicolumn{5}{|l|}{ Marriage period $(1870-79=$ ref. $)$} \\
\hline $1880-1899$ & 0.65 & 0.56 & 1.19 & 3.01 \\
\hline 1900-1919 & 0.85 & $0.57^{*}$ & 1.26 & 2.01 \\
\hline $1920-1934$ & $0.41^{*}$ & $0.29 * * *$ & 0.52 & 1.44 \\
\hline \multicolumn{5}{|l|}{$\begin{array}{l}\text { Death of parents } \\
\text { (parents alive }=\text { ref.) }\end{array}$} \\
\hline Husband's father dead & 1.18 & 1.35 & $1.82 * * * *$ & 0.81 \\
\hline Husband's mother dead & 0.74 & 1.12 & $2.43 * * * *$ & $1.76^{* *}$ \\
\hline Wife's father dead & 1.20 & $1.54 * *$ & $1.60 * * *$ & 1.30 \\
\hline Wife's mother dead & 0.93 & 0.99 & $1.58 * * *$ & $1.55^{*}$ \\
\hline \multicolumn{5}{|c|}{ Age of the husband $(25-34=$ ref. $)$} \\
\hline Younger than 25 & 1.34 & 0.83 & 1.17 & 1.35 \\
\hline Older than 34 & 1.61 & 1.63 & 1.30 & 1.22 \\
\hline \multicolumn{5}{|l|}{ Age of the wife $(25-34=$ ref. $)$} \\
\hline Younger than 25 & 1.54 & 0.78 & 0.99 & 0.73 \\
\hline Older than 34 & 1.15 & 0.74 & 0.73 & 1.33 \\
\hline \multicolumn{5}{|l|}{ Number of surviving siblings } \\
\hline Older siblings & $0.86^{* *}$ & 0.96 & 1.02 & 0.95 \\
\hline Younger siblings & $0.77 * * * *$ & $0.81 * * * *$ & $1.11^{* * * *}$ & 0.93 \\
\hline Number of surviving children & $0.72 * * *$ & 1.04 & 1.00 & 0.98 \\
\hline \multicolumn{5}{|l|}{ Migration experience } \\
\hline Husband migrated & 0.74 & 0.98 & 1.04 & $0.57 * *$ \\
\hline Wife migrated & 0.70 & 1.05 & 1.22 & 1.14 \\
\hline
\end{tabular}


TABLE 6 (cont.)

\begin{tabular}{|c|c|c|c|c|}
\hline & $\begin{array}{l}2: \text { Co- } \\
\text { residence } \\
\text { with } \\
\text { parents }\end{array}$ & $\begin{array}{c}\text { 3: Extended } \\
\text { with } \\
\text { parents }\end{array}$ & $\begin{array}{l}\text { 4: Co- } \\
\text { residence } \\
\text { with } \\
\text { siblings }\end{array}$ & $\begin{array}{l}\text { 5: Co- } \\
\text { residence } \\
\text { combined } \\
\text { or with } \\
\text { other kin }\end{array}$ \\
\hline $\mathrm{N}$ & 81 & 128 & 214 & 87 \\
\hline Model chi-square & $426.1^{* * * *}$ & & & \\
\hline Nagelkerke's r-square & 0.131 & & & \\
\hline
\end{tabular}

$* 0.1 ; * * 0.05 ; * * * 0.01 ; * * * * 0.001$

${ }^{a}$ See endnote 44 on the occupational-group/social-class categories used here.

Source: HSN Data Set Life Courses Release 2008.01, International Institute of Social History, Amsterdam; marriage certificates from HSN Data Set Civil Certificates Release 2007.01. The entire dataset consists of 21,487 persons born between 1850 and 1922 ; from this group persons were selected who married before 1935. Also, the certificate of (first) marriage had to be in the database. We have removed persons with an elite or unknown occupation, as the numbers involved were too small to be processed properly.

when all their children had left. Finally, the preference for wives' widowed mothers above other parents is suggestive of a strong bond between mothers and daughters.

Taking in siblings (as in group 4) was only loosely associated with the needs of the receiving family. On the one hand, we do find a higher likelihood among farmers, who could use the labour of their siblings-in-law. On the other, we witness a very strong association with the death of the parents, suggesting altruistic motives. Why did couples in cities take in siblings more often than rural couples? Did this stem from the need of unmarried persons to find housing? Or were the couples interested in supplementing the rent by taking in kin? The latter motive seems unlikely, as those who could use additional income the most, the unskilled workers, were less likely to take in siblings. Overall, altruistic motives for helping family members seem to have predominated.

Finally, we take a look at the category of more distant kin as well as combinations (group 5). Because of the heterogeneous character of this category, interpretation is more difficult. In this case, altruistic motives seem less important: the association with the death of the parents is still there, but weaker than in the case of siblings. Middle-class couples did not take in distant kin (or closer kin, for that matter) more often than other couples. Also, migrant men were less likely to take in kin than natives, which goes counter to the idea found in studies on chain migration that migrants were eager to help kin from their native areas. On the other 
hand, farming couples and couples in the stem-family area did take in more distant kin.

\section{CONCLUSION}

In this article, we have used a large dataset (the Historical Sample of the Netherlands) with reconstructed life courses in order to study variations in co-residence with kin in the Netherlands in the late nineteenth and early twentieth centuries. The life-course approach allows us to look at coresidence from two perspectives: that of the people deciding to co-reside in another household and that of the households taking in relatives. This double-sided approach gives us a better view on the motives underlying co-residence. We distinguish between, on the one hand, family-related motives - in which the desire to help relatives in need stand out - and on the other hand rational choices - in which co-residence was a strategic move to further one's career or to improve the household's economy. Furthermore, our approach enables us to control to some extent for the 'pool' of kin available for co-residence.

The variation in co-residence with kin in the Netherlands is mainly based on two underlying principles. The first is the persistence of inheritance customs in the eastern border areas, where succession to farms and headship was delayed and senior and junior couples co-reside. To some extent, the practice was also found in non-farming families in this area, and spread out to the central-western part of the country as well. In the north-western part of the country, the norm of neo-locality was very predominant. The second principle was the urge to help out close kin, in particular siblings (especially the unmarried). Co-residence with siblings was closely related to the death of a parent. Also, it seems that households that had difficulties with coping (such as young parents with many children) sent some children away to live with relatives. Apart from farming families, we have not found many indications that co-residence was governed by 'strategic' motives: families who had migrated were not selected by young persons as convenient households to live in, nor were they keen on taking in kin themselves.

Although it is clear that the Netherlands was among the heartlands of the western European nuclear-family system, there were also parts of the country that seem to have belonged to the more central and northernEuropean 'stem-family area'. Our analysis has confirmed that these regional differences were 'real', that is, they are not accounted for by compositional effects of urbanization or class. We have also confirmed that household extensions were more prevalent in rural settings than in urban ones, and occurred more among farmers than among other social 
groups. The decline in co-resident kin that we observed confirms the preliminary conclusions based on the censuses, in which kin were not singled out as a separate category.

Although our multivariate analysis has revealed backgrounds of coresidence patterns and choices for particular types of kin, we should keep in mind that the great majority of households were still nuclear. Also, our analysis of the life courses of 70-year-olds (not in the stem-family region) has suggested that those who never married were not particularly welcomed by their relatives. Thus, co-residence remained - apart from in the south-eastern areas - a rare departure from the nuclear standard.

\section{ENDNOTES}

1 E.g. T. Bengtsson, C. Campbell and J. Z. Lee eds., Life under pressure: mortality and living standards in Europe and Asia, 1700-1900 (Cambridge MA, 2004); D. I. Kertzer and D. P. Hogan, Family, political and demographic change: the transformation of life in Casalecchio, Italy, 1861-1921 (Madison, 1989); J. Z. Lee and C. D. Campbell, Fate and fortune in rural China: social organization and population behavior in Liaoning, 1774-1873 (Cambridge, 1997); R. Derosas and M. Oris eds., When dad dies: individuals and families coping with distress in past societies (Bern, 2002); G. Alter, M. Dribe and F. van Poppel, 'Widowhood, family size, and post-reproductive mortality: a comparative analysis of three populations in nineteenth-century Europe', Demography 44/4 (2007), 785-806; M. Durães, A. Fauve-Chamoux, L. Ferrer and J. Kok eds., The transmission of well-being: gendered marriage strategies and inheritance systems in Europe (17th20th centuries) (Bern, 2009).

2 G. Alter and M. Oris, 'Childhood conditions, migration, and mortality: migrants and natives in nineteenth-century cities', Social Biology 52/3-4 (2005), 178-91.

3 E.g. R. A. Settersten ed., Invitation to the life course: toward new understandings of later life (Amityville, 2002).

4 E.g. M. Szołtysek, 'Central European household and family systems, and the HajnalMitterauer line: the parish of Bujakow (18th-19th centuries)', History of the Family 12/1 (2007); M. Szołtysek, 'Three kinds of preindustrial household formation system in historical Eastern Europe: a challenge to spatial patterns of the European family', History of the Family 13/3 (2008), 223-57.

5 A. Fauve-Chamoux and E. Ochiai eds., The stem family in Eurasian perspective: revisiting house societies, 17th-20th centuries (Bern, 2009).

6 M. S. Hartman, The household and the making of history: a subversive view of the western past (Cambridge, 2004); T. de Moor and J. L. van Zanden, Vrouwen en de geboorte van het kapitalisme (Meppel, 2006).

7 L. L. Cornell, 'Household studies: a review essay', Historical Methods 19 (1986), 3, 133.

8 F. van Poppel, M. Oris and J. Lee eds., The road to independence: leaving home in western and eastern Societies, 16th and 20th centuries (Bern, 2003); H. Bras, 'Social change, service and youth in the lives of rural-born Dutch women, 1840-1940, Continuity and Change 19/2 (2004), 241-264; M. Dribe and C. Lundh, 'Determinants of servant migration in nineteenth-century Sweden', Continuity and Change 20/1 (2005), 53-91. 
9 E. A. Hammel and P. Laslett, 'Comparing household structure over time and between cultures', Comparative Studies in Society and History 16 (1974), 73-110, 99.

10 Hammel and Laslett, 'Comparing household structure', 98.

11 D. I. Kertzer, Family life in central Italy, 1880-1910: sharecropping, wage labor, and coresidence (New Brunswick NJ, 1984) 205. See also G. H. Elder, 'Family history and the life course', Journal of Family History 2 (1977), 279-304, and M. A. Vinovskis, 'From household size to the life course: some observations on recent trends in family history', American Behavioral Scientist 21 (1977), 263-87.

12 R. Wall, 'Widows: perceptions, demography, residence patterns, and standards of living', History of the Family 7/1 (2002), 3-12.

13 S. Ruggles, Prolonged connections: the rise of the extended family in nineteenth-century England and America (Madison, 1987), 'The transformation of American family structure', The American Historical Review 99/1 (1994), 103-28, and 'Multigenerational families in nineteenth-century America', Continuity and Change 18/1 (2003), 139-65.

14 J. E. Smith, 'Method and confusion in the study of the household', Historical Methods 22 (1989), 57-69; M. King, 'All in the family? The incompatability and reconciliation of family demography and family history', Historical Methods 23 (1990), 32-40; D. I. Kertzer, 'Household history and sociological theory', Annual Review of Sociology 17 (1991), 155-79; S. Ruggles, 'Confessions of a microsimulator: problems in modeling the demography of kinship', Historical Methods 26/4 (1993), 161-9.

15 See Ruggles, Prolonged connections.

16 The HSN totals 78,000 research persons from the birth period 1812-1922 and is located at the International Institute of Social History in Amsterdam (IISH); for more information about the databases see www.issg.nl/hsn (email HSN@iisg.nl). See also K. Mandemakers, 'The Netherlands. Historical Sample of the Netherlands', in P. Kelly Hall, R. McCaa and G. Thorvaldsen eds., Handbook of international historical microdata for population research (Minneapolis, 2000).

17 J. A. Verduin, 'Het gezin in demografisch perspectief', in G. A. Kooy ed., Gezinsgeschiedenis: vier eeuwen gezin in Nederland (Assen and Maastricht, 1985), 69-110.

18 A. M. van der Woude, 'Bevolking en gezin in Nederland', in F. L. van Holthoon ed., De Nederlandse samenleving sinds 1815: wording en samenhang (Assen, 1985).

19 Verduin, 'Het gezin', 72.

20 C. de Hoog, C. Huishouden, huwelijk en gezin, Interimrapport Censusmonografieën (Amsterdam, 1976).

21 G. A. Kooy, Het veranderend gezin in Nederland (Assen, 1957).

22 A. M. van der Woude, Het Noorderkwartier: een regionaal-historisch onderzoek in de demografische en economische geschiedenis van westelijk Nederland van de late middeleeuwen tot het begin van de negentiende eeuw (Wageningen, 1973).

23 Verduin, 'Het gezin', 75.

24 G. A. Kooy, De oude samenwoning op het nieuwe platteland: een studie over de familiehuishouding in de agrarische Achterhoek (Assen, 1959).

25 J. Lucassen, Migrant labour in Europe 1600-1900: the drift to the North Sea (London, Sydney, and Wolfeboro NH, 1987).

26 Summarized in H. de Haan, In the shadow of the tree: kinship, property and inheritance among farm families (Amsterdam, 1994).

27 D. van Blom, 'Boerenerfrecht (met name in Gelderland en Utrecht)', De Economist 64 (1915), 849-98.

28 Kooy, De oude samenwoning, 14-24.

29 Verduin, 'Het gezin', 89. 
30 S. Rijpma, 'The extended family revisited', in C. de Hoog, L. Th. van Leeuwen, Q. J. Munters and C. J. Weeda eds., Tussen empirie en reflectie: verzamelde opstellen voor G. A. Kooy (Wageningen, 1985), 53-6.

31 Van Blom, 'Boerenerfrecht', e.g. p. 873.

32 De Haan, In the shadow of the tree, 115-16.

33 D. Damsma and J. Kok, 'Ingedroogde harten? Partnerkeuze en sociale reproductie van de Noord-Hollandse boerenstand in de negentiende en vroeg-twintigste eeuw', in J. Kok and M. H. D. van Leeuwen ed., Genegenheid en gelegenheid: twee eeuwen partnerkeuze en huwelijk (Amsterdam, 2005); H. Bras and T. van Tilburg, 'Kinship and social networks: a regional analysis of sibling relations in twentieth-century Netherlands', Journal of Family History 32 (2007), 296-322.

34 J. Kok and K. Mandemakers, "“Je zoudt maar last van mij hebben": verwanten in het Nederlandse huishouden, 1860-1940', Tijdschrift voor Sociale en Economische Geschiedenis 6 (2009), 139-65.

35 A. Janssens, Family and social change: the household as a process in an industrializing community (Cambridge, 1994).

36 Ruggles, Prolonged connections, 11, 134.

37 B. de Vries, 'Familiehulp 1800-1890', in J. van Gerwen and M. H. D. van Leeuwen eds., Studies over zekerheidsarrangementen: Risico's, risicobestrijding en verzekeringen in Nederland vanaf de Middeleeuwen (Amsterdam and The Hague, 1998), 472.

38 E. A. M. Bulder, The social economics of old age: strategies to maintain income in later life in the Netherlands 1880-1940 (Groningen, 1993) 168.

39 Mandemakers, 'The Netherlands'.

40 For the way in which the life courses were constructed from the population registers, see K. Mandemakers, 'Building life course datasets from population registers by the Historical Sample of the Netherlands (HSN)', History and Computing 14 (2006), $87-107$.

41 C. Gordon, The Bevolkingsregisters and their use in analyzing co-residential behaviour of the elderly (The Hague, 1989), Nederlands Interdisciplinary Demographic Institute (NIDI) report 9.

42 As the registers for 1850-1862 are not detailed enough, we have used information on persons born in 1850 from their thirteenth birthday onwards, those born in 1851 from their twelfth birthday, and so on.

43 The south-east is the provinces of Limburg, Gelderland and Overijssel; the south-west is those of Utrecht, Zeeland and Noord-Brabant; and the north-west is the provinces of North-Holland, South-Holland, Groningen, Drenthe and Friesland.

44 Our social-class categories are derived from HISCLASS, in itself based on the HISCOcoding scheme; see M. H. D. van Leeuwen, I. Maas and A. Miles, HISCO: Historical International Standard Classification of Occupations (Leuven, 2002); M. H. D. van Leeuwen, I. Maas and A. Miles, Marriage choices and class boundaries: social endogamy in history (Cambridge, 2005).

45 S. Menard, Applied logistic regression analysis (Thousand Oaks CA, London and New Delhi, 1995).

46 Such an analysis would be feasible with competing risks event history analysis; see K.Yamaguchi, Event history analysis (Newbury Park CA, 1991). However, this requires even more detailed information on the timing of events than we have.

47 C. Pooley and J. Turnbull, Migration and mobility in Britain since the eighteenth century (London, 1998).

48 M. J. Maynes, Taking the hard road: life course in French and German worker's autobiographies in the era of industrialization (Chapel Hill and London, 1995); 
M. Mitterauer, A history of youth (Oxford, 1992); and J. Kok, 'Youth labor migration and its family setting: the Netherlands 1850-1940', The History of the Family 2 (1997), $507-26$.

49 Janssens, Family and social change.

50 The 10,814 youths were born in the period 1850-1918, were still unmarried and are 'observed' on their twentieth birthday: that is, the database contains information on their household situation on that date.

51 Kok, 'Youth labor migration'.

52 This may in part be attributed to the change (around 1920) in administrative practices in which co-resident kin were increasingly relegated to special cards for solitary persons.

53 S. Coontz, Marriage, a history: how love conquered marriage (New York, 2005), 183, 184, 207; Ruggles, Prolonged connections. 